\title{
Politiikan teoria ennen 1900-lukua
}

\author{
Petri Koikkalainen ja Paul-Erik Korvela (toim.) (2012). \\ Klassiset poliittiset ajattelijat. Tampere: Vastapaino. $526 \mathrm{~s}$. \\ ISBN 978-951-768-373-9.
}

GAUDEAMUS JULKAISI 1980- ja 1990-lukujen taitteen tienoilla Jukka Kanervan toimittamana teokset Platonista Bakuniniin: Politiikan teorian Klassikoita ja Politiikan teorian moderneja klassikkoja. Nyt Vastapainon julkaisemassa kokoelmassa on melkein kaikki Kanervan ensimmäisen kirjan klassikkonimistä. Uusimmat ovat Marx ja Nietzsche. Heitä uudemmat teoreetikot ovat jo saaneet oman kokoelman vuonna 2008 Kia Lindroosin ja Suvi Soinisen toimittamassa teoksessa Politiikan teorian nykyteoreetikkoja (Gaudeamus). 1900-luvun jälkipuoliskon klassikoista keskustelluin John Rawls (1921-2002) sai tänä keväänä oman kokoelmansa Gaudeamuksen kustantamana. Sitä ennen Gaudeamus ehti saattaa julki Kaisa Herneen kirjan oikeudenmukaisuudesta. Aikamme demokratian ongelmat eittämättä lisäävät kiinnostusta poliittiseen filosofiaan, tai politiikan teoriaan, sen uusiin analyyseihin, tulkintoihin ja teoretisointeihin.

Klassiset poliittiset ajattelijat -kirjassa analysoidaan kuudentoista klassikon ajatuksia. Mukana ovat Platon, Aristoteles, Cicero, Aurelius Augustinus, Tuomas Akvinolainen, Niccoló Machiavelli, Thomas Hobbes, John Locke, David Hume, Jean-Jacques Rousseau, Edmund Burke, G.W.F. Hegel, John Stuart Mill, Marx ja Nietzsche.

Kirjan artikkeleissa pidetään silmällä erityisesti länsimaisen poliittisen ajattelun pitkäkestoisten teemojen esiintyvyyttä ja käsittelyä teoreetikoiden ajattelussa. Näitä ovat kysymykset ihmisluonnosta ja parhaasta poliittisen yhteisön muodosta, maallisen ja kirkollisen vallan suhteesta, poliittisten yhteisöjen välisistä eli kansainvälisistä suhteista, historiallisesta edistyksestä. Kirjan toimittajat kehottavatkin kysymään, millaisia yhteisömuotoja tai valtarakenteita teoreetikkojen esittelemät ajatukset ja teoriat ovat kulloinkin tukeneet.

\section{PLATON}

Politiikan teorian länsimainen historia Platonista alkaen on oppia poliksen eli kaupunkivaltion oikeasta järjestämisestä. Politiikan teoria onkin usein utopia hyvästä yhteiskunnasta, siitä miten yhteiskuntaelämä pitäisi järjestää, millainen hallitsijan tulisi olla, millaisia oikeuksia ja velvollisuuksia hallitsijoilla ja hallituilla tulisi olla, ja miten valtion asioita tulisi hoitaa. Mitä esimerkiksi ovat oikeudenmukaisuus, tasa-arvo ja vapaus, ja miten niiden keskinäinen painoarvo määräytyy jos, ja kun, ne joutuvat ristiriitaan keskenään?

Yhteen Ateenan näkyvimpiin aristokraattisiin sukuihin syntyneen Platonin kirjoituksia ja ajatuksia on käytetty aikojen saatossa yhteen jos toiseenkin tarkoitukseen. Valtiossa Platon hahmotteli oikeudenmukaisen yhteiskunnan, jossa vallan perusta ei olisi vahvemman ylivoima vaan maailmanjärjestyksen ja universaalin hyvän käsittäminen. Ihannevaltio on ankaran hierarkkinen ja vahvasti demokratianvastainen. Se perustuu ihmisten synnynnäisiä kykyjä vastaavalle työnjaolle. Yhteisön hyvinvointi menee yksilön vapauden edelle. Myöhemmin Laeissa Platon luopui ankaran hierarkkisuuden vaatimuksesta 
laajemman poliittisen osallistumisen hyväksi.

Demokratianvastaisuus kumpuaa Platonilla siitä, että Ateenan demokratiassa valtaa käytti kansa, eli vapaat, sotapalveluksen suorittaneet miehet, joiden äänioikeus oli Platonin mielestä pikemminkin häiritsevää kuin hyödyllistä. Viisaat, filosofiaan perehtyneet miehet olivat parhaita päättämän valtion asioista. Naiset miehiä keskimäärin vähempilahjaisina eivät poikkeuksia lukuun ottamatta sopineet päätöksentekijöiksi. Kansalaiset piti Platonin mukaan suunnitelmallisesti kasvattaa osaksi valtion rattaita, jotta heistä ei olisi häiriötä. Valtion ja Lakien yksi keskeinen teema onkin kasvatus. Kasvatuksen välityksellä sopivat myytit ("jalot valheet") omaksunut kansa pysyisi paremmin koossa. Nämä ajatukset eivät ole vieläkään vanhentuneet. Myyttien ylläpitäminen ja juurruttaminen kasvaviin kansalaisiin on totta tänäkin päivänä. Platonin ajatukset autoritaarisesta kasvatuksesta muuttuvat tuotannon myötä argumentoivan kasvatuksen suuntaan.

\section{ARISTOTELES, AUGUSTINUS \& MACHIAVELLI}

Aristoteleskaan ei kannattanut naisten hyväksymistä mukaan valtiolliseen toimintaan. Aristoteles piti luonnontieteellisenä faktana, että naisen hallitseva sielunosa on luonnostaan heikko. Yksilön luonne ja arvostukset kuitenkin muovautuvat lapsuudessa ja nuoruudessa kasvatuksen seurauksena. Tapakulttuurin säännöt ovat kirjoitettuja lakeja tärkeämpiä. Aristoteleelle toiminnalliset tottumukset ovat järkeä vahvempia: "kasvattajan tulee ensin saada aikaan tottumuksia ja vasta sitten vedota järkeen.” Tämä kävi ohjenuoraksi myös päättäjille: lainsäätäät voivat tehdä kansalaisista hyviä juurruttamalla heihin oikeita tottumuksia. Kun kansalaiset ovat hyviä, valtio on hyvä.

Aristoteles ei kuitenkaan uskonut tyranniaan: sellaiset valtiomuodot, joissa kansan enemmistön oikeustajua toistuvasti loukataan, eivät ole elinkelpoisia. Siinä missä Aristoteleen ihmiskäsitys oli kasvatuksen suhteen toiveikas, Aurelius Augustinus (354-439) piti ihmistä surkeana ja kieroutuneena olentona, joka oli pidettävä kurissa pakkokoneistoilla. "Vainoojien ruhtinas" Augustinuksella olikin huomattava vaikutus pakkokäännyttämisiin ja miekkalähetykseen.

Pitkälle keskiajalle saakka politiikan teoriaa tehtiin enimmäkseen yhteiskunnallisen sopusoinnuttamisen idean perustalle. Teorioissa luotiin utopioita sopusointuisista yhteisöistä. Niccolo Machiavellin (1469-1527) ajatusten myötä politiikan teoriaan tuli selkeästi mukaan ryhmäkohtaisten intressien ajamiseen perustuva realistisempi politiik- kakonseptio. Machiavellin tekstit ovat myös saaneet taipua monien keskenään ristiriitaisten ajatusten palvelukseen. Ne ovatkin monitulkintaisia ja sisäisesti inkoherentteja. Machiavellille on samantekevää, onko hallitsija tyranni vai hyveellinen. Hän ei puhu vallan moraalisesti oikeasta käytöstä vaan sen tehokkuudesta, ja siitä, mitä hallitsijan kannattaa tehdä pysyäkseen vallassa. Johtaminen (tai oikeammin hallitseminen) on Machiavellille moraalista riisuttua tekniikkaa. Moraalista on hallitsijalle vain haittaa, ja toisiin luottaminen on tyhmyyttä. Viisas hallitsija mukautuu olosuhteisiin: koska olosuhteista ei voi kontrolloida, niitä on osattava käyttää opportunistisesti hyväksi: "hulluina aikoina pärjäävät hullut”. Mutta missä tyylilajissa Machiavellin pääteos Ruhtinas on kirjoitettu, ei ole selvää. Onko se tasavaltalaisen kirjoittama satiiri vai opaskirja tyrannille?

\section{HEGEL \& MILL}

1800-luvulla monet filosofit ajattelivat, että ihmiskunta oli kehittymässä kohti laadullisesti uutta aikakautta. G.W.F. Hegel (17701831) oli puhunut "hengen kehittymisestä” kohti yhä korkeampia muotoja, ja valtiossa järki saavuttaisi historiallisen huippunsa. Samalla ihmisen tietoisuus kehittyisi korkeimmalle eli filosofiselle asteelle syrjäyttäen aiemmat taiteelliset ja uskonnolliset ilmene- 
mismuodot. Sosiologia-tieteen isäksikin nimitetty Auguste Comte (1798-1857), joka ei hyväksynyt Hegelin "hengen" ja "järjen" kaltaisia abstraktioita, uskoi sosiologian nousevan korkeimmaksi tieteeksi, joka kaikkien muiden tieteiden löydöksiä ja havaintoja apuna käyttäen tarjoaisi lopullisen ymmärryksen yhteisöistä ja niiden hallinnasta. Comte puolustikin positiiviseen tietoon perustuvaa keskitettyä asiantuntijoiden (sosiologien) valtaa. 1800-luvulla kansalaisista muodostuvasta väestöstä ja kansantaloudesta tuli yhä selkeämmin yhteiskuntatieteiden ja talous- ja sosiaalipolitiikan kohteita.

Comte ja John Stuart Mill (1806-1873) olivat jonkin aikaa tiiviissä kirjeenvaihdossa keskenään, mutta erkaantuivat näkemyksissään. Mill oli edustuksellisen demokratian kannattaja, joskin hän katsoi, että koulutetun eliitin tulisi voida hyväntahtoisesti sivistää oppimaton kansa riittävälle sivistystasolle. Hän oli myös sukupuolten tasa-arvon kannattaja. Naista alistavat tavat, säännökset ja käytännöt olivat Millin mukaan naisten alistamisen ydin. Se, mikä oli muodostunut tavanomaiseksi, alkoi vähitellen näyttää luonnolliselta, minkä vuoksi naisten alisteinen asema oli alettu ymmärtää osaksi heidän biologista olemustaan, Mill opetti. Miehet ja naiset eivät kuitenkaan olleet ominaisuuksiltaan samanlaisia.
Naiset olivat käytännöllisempiä, etevämpiä ihmisten tarkkailijoita, parempia näkemään yksittäisten tapausten erityispiirteet, henkisesti liikkuvaisempia ja kykeneviä suoriutumaan useista samanaikaisista tehtävistä. Millin mukaan naiset soveltuivat miehiä paremmin esimerkiksi monarkeiksi ja pääministereiksi. Edustuksellinen demokratia rakentui puolueiden joukkokannatuksen varaan, minkä vuoksi Mill näki politiikan myös kasvatuksellisena projektina: poliittisiin periaatteisiin perehtyneet ja omista periaatteistaan vakuuttuneet kansalaiset olisivat parhaita äänestäjiä ja politiikan toimihenkilöitä. Millin aikana voidaankin sanoa alkaneen ideologisen politiikan kauden. Tuolloin politiikka alkoi näyttäytyä myös vapauden ja tasa-arvon periaatteiden välisenä kamppailuna. Vapauden ja tasaarvon välisen jännitteen kautta tuli myös vedettyä oikeiston ja vasemmiston välinen rajalinja ainakin yli sadaksi vuodeksi.

\section{MARX \& NIETZSCHE}

Marxin (1818-1883) rönsyilevät kirjoitukset ovat olleet paitsi vaikutusvaltaisia myös alttiita väärintulkinnoille. Marx ei koskaan rakentanut hyvän yhteiskunnan kuvausta, vaan keskittyi Engelsin tuella aikansa kapitalismin analysoimiseen. Marx kirjoitti monessa tyylilajissa, mikä on sekin johtanut vulgaareihin tulkintoihin. Valtio on kapitalismissa luokkavaltio, jonka kautta porvarisluokka pyrkii esittämään omat luokkaetunsa koko kansakunnan yleisenä etuna. Pikemmin kuin politiikan teoriaa normatiivisessa mielessä tämä on sosiologiaa. Luokkaherruus koskee myös koulutusta: mitä koulussa opetetaan, perustuu hallitsevan luokan ideologiaan. Vallassa olevien luokkaetua palvelevaa ideologia juurrutetaan kansalaisiin totuutena.

Viimeisenä kirjassa esiteltävän Friedrich Nietzschen (18441900) teosten tulkinnassa on "sadan vuoden aikana toteutunut kirjaimellisesti uskomaton kavalkadi lukutapoja totunnaisten poliittisten karttojen joka kolkassa” (s. 488). Nietzsche kuvasi itseään "ajatusmadoksi, joka ei piittaa sen enempää politiikasta kuin nykyajasta”. Yleensä nihilistinä pidetty Nietzsche on ehkä ennen muuta liberalismin kriitikko, joka kantoi huolta yksilöllisyydestä tapojen, järjestelmien ja enemmistöjen puristuksessa. Nationalismi oli vesittänyt liberalismin ja aito yksilöllisyys ja yksilöllinen suuruus olivat vaarassa tuhoutua. Nietzsche on kova pala tutkijalle.

Kirjan toimittajat varoittelevat esittämisaikaansa sidottujen käsitteiden soveltamisesta nykyaikana: "Antiikin Kreikan polis on yhtä vähän valtio kuin kaislavene on höyrylaiva, eikä niiden johtaminen ole 'sama asia'. Siten emme voi puhua myöskään Platonin valtiokäsityksestä, koska hänellä ei ollut 
valtion käsitettä samassa mielessä kuin me sen ymmärrämme. Vielä Machiavellillakin lo stato on persoonalliseen vallankäyttöön sidottu käsite eikä sinällään vastaa modernia, persoonattoman valtion käsitettä. Machiavellilla ei myöskään ollut sanaa sille, mitä nykyään kutsuttaisiin johtamiseksi, vaikka hänen kirjoituksiaan onkin monesti luettu johtamisen opaskirjoina." (s. 16)

\section{TULKITSEMISEN VAIKEUDET}

Viime vuosisadan jälkipuoliskolta alkaneelle "uudelle poliittisen ajattelun historialle" on ollut keskeistä korostaa kontekstien merkitystä: ajattelu ja käsitteet muuttuvat jatkuvasti, ja aatteet, arvot ja käsitteet muotoutuvat valtakamppailujen tuloksena eikä vain filosofisina ideoina. Pariisissa ajatusjärjestelmien historian professorina toimineen Michel Foucault'n vanavedessä tapahtuneen kielellisen käänteen jälkeen politiikkaa ja filosofiaa alettiin tutkia kielellisenä tai diskursiivisena toimintana, jossa kullekin ajalle tyypilliset puhetavat ja niihin kytkeytyvät valta-asetelmat asettavat ehtoja sekä ongelmien esiin nostamiselle että niihin vastaamiselle. Se, mitä on mahdollista ajatella, riippuu olosuhteista.

Klassisiksi ajattelijoiksi nostettujen filosofien teksteistä ei suinkaan aina muodostu yhtä koherenttia kokonaisuutta. Siihen on useita syitä. Ensinnäkin, työkseen ajattelevat ja ajatusrakennelmia kehittelevät oppivat elämänuransa aikansa kaikenlaista uutta tutkimuskohteestaan ja sen vuoksi heidän käsityksensä muuttavat. Se kuuluu tieteellisen ajattelun luonteeseen. Tästä käy esimerkkinä Edmund Burke (1729-1797), jota pidetään konservatismin isänä, mutta jonka Vindication on anarkismin klassikkoteos. Jälkipolvi vain on monta kertaa taipuvainen joko unohtamaan osan kirjoituksista tai lukemaan eri aikoina tuotetut ja keskenään huonosti yhteen sopivat ajatukset yhdeksi kokonaisuudeksi. Usein vasta tulkitsijat muodostavat hajanaisista kirjoituksista "opin".

Toiseksi, klassikoidenkaan ajatusrakennelmat ja teoriat eivät ole täydellisiä siinä mielessä, että niistä muodostuisi politiikan kaikki osa-alueet kattava esitys tai teoria, jossa käsitteet olisi eksplikoitu yksiselitteisesti ja niiden keskinäiset suhteet ajateltu loppuun saakka. Esimerkiksi Aristoteleen kirjoituksista ei voi muodostuakaan kokonaisuutta, koska osa niistä on kadonnut.

Kolmanneksi, monien filosofien kirjoitukset ovat kommentteja edeltävien ajattelijoiden (tai aikalaisten) käsityksiin tai ajankohtaisiin kysymyksiin, minkä vuoksi tekstien syntykontekstilla on erityinen merkitys, joka myöhempien tulkitsijoiden olisi tunnettava. Tämä tulee erityisen hyvin esiin Augustinuksen kohdalla. Tulkit- sijoiden on siis hyvä ottaa selville, miksi tutkimuksen kohteena oleva teoreetikko on milloinkin tuntenut tarvetta ottaa jokin asia puheeksi. Monta kertaa syynä on ollut vastaaminen päiväkohtaiseen keskusteluun tai jonkin toisen teoreetikon (usein poleemisten) ajatusten kommentointi.

Täydellisen historiallisen rekonstruktion tekeminen on mahdotonta. Käytännössä sen yrittäminenkään ei ole mielekästä, vaikka niin tietysti tehdään kaiken aikaa. Millaisten perusteiden varassa entisaikojen filosofit ovat teoriansa luoneet, ei aina selviä heidän teksteistään. Eivätkä myöhemmät tulkitsijat voi varmuudella sanoa, mitä tulkittavan filosofin on teoriaa muotoillessaan "täytynyt tietää".

"Poliittisen ajattelun historia näyttää, että kaikki ihmisen luoma voisi olla toisinkin." (s. 7.)

Heikki Silvennoinen

professori

Turun yliopisto 